\title{
POLITIK HUKUM KRIMINALISASI DAN DEKRIMINALISASI DI BIDANG HAK CIPTA
}

\author{
(Legal Politics of Criminalization and Decriminalization in \\ Copyright)
}

\author{
Duwi Handoko \\ Sekolah Tinggi IImu Hukum Persada Bunda \\ Jalan Diponegoro Nomor 42 Kota Pekanbaru, 28116 \\ Telp. 081319711721 \\ sepihak@gmail.com
}

\section{Tulisan diterima: 15 Desember 2018; Direvisi: 6 Maret 2019; \\ Disetujui Diterbitkan: 13 Maret 2018}

DOI:

\begin{abstract}
Abstrak
Substansi Undang-Undang Hak Cipta di Indonesia, meliputi aspek hukum privat dan hukum publik. Dalam tulisan ini, hanya dikaji unsur hukum publik, khususnya terkait kriminalisasi dan dekriminalisasi. Penelitian ini dilandasi oleh keingintahuan dalam mengungkap dasar pemikiran kriminalisasi dan dekriminalisasi untuk mencapai tujuan, yaitu setiap orang harus mengetahui batasan-batasan terhadap suatu perbuatan yang dapat dipidana. Pendekatan yang digunakan dalam penelitian ini adalah secara kualitatif dengan alat pengumpul data berupa studi kepustakaan. Kriminalisasi dan dekriminalisasi di bidang hak cipta adalah bagian dari Politik Hukum Pidana Indonesia. Dasar pemikiran proses kriminalisasi dapat ditinjau dari dua aspek, yaitu kriminalisasi murni dan bukan kriminalisasi murni. Dasar pemikiran proses dekriminalisasi adalah pidana tidak dijatuhkan atas perbuatan pelanggaran hak cipta yang tidak memiliki kepentingan secara komersial. Pemerintah hendaknya secara terus menerus memberikan edukasi kepada pencipta atau pemegang hak cipta dalam menyikapi delik aduan di bidang hak cipta. Pencipta hendaknya terus berkarya dan memahami bahwa tidak semua pelanggaran hak cipta dapat dinyatakan sebagai kejahatan dan terhadap pelakunya disebut penjahat. Hal itu karena ada legalisasi terhadap pelanggaran itu sendiri.
\end{abstract}

Kata Kunci: hak cipta; politik hukum; hukum pidana; kriminalisasi; dekriminalisasi.

\begin{abstract}
The substance of the Indonesian Copyright Law covers the Private Law and Public Law aspects. In this paper, only the public law aspects are reviewed, specifically related to criminalization and decriminalization. This research is based on curiosity in revealing the ground for criminalization and decriminalization ideas to achieve goals, i.e. one must know the limits of an action that may be classified as a crime or nor. The approach used in this research is qualitative approach with data collection tool in the form of library studies. The criminalization and decriminalization in copyright is part of the Indonesian Criminal Law Politics. The rationale for the criminalization process may be viewed from two aspects, the pure crime and non-pure crime. The rationale for the decriminalization process is that the acts of copyright infringement should not be charged under the criminal laws if such copyright has nothing to do with the commercial interest. The government should continuously provide education to the creators or copyright holder in dealing with the requirements of police reporting in regard to the copyright infringement. The creator should keep on producing works and should be made understand that not all copyright infringement may be charged under the penal code and not all such culprits may be classified as a criminal. Since there have been some infringement are legalized.
\end{abstract}

Keywords: copyright; legal politics; criminal law; criminalization; decriminalization. 


\section{PENDAHULUAN}

\section{Latar Belakang}

Tidak ada suatu bangsa di dunia ini yang tidak mempunyai hukumnya sendiri. Tiap-tiap bangsa mempunyai tata hukumnya sendiri, demikian juga bangsa Indonesia mempunyai tata hukum sendiri, Tata Hukum Indonesia. ${ }^{1}$

Aturan-aturan hukum yang berlaku di Indonesia berkembang secara dinamis sesuai perkembangan zaman dan perkembangan kebutuhan masyarakat. Oleh karenanya suatu aturan yang sudah tidak memenuhi kebutuhan masyarakat perlu diganti dengan yang baru. ${ }^{2}$

Suatu aturan yang sudah tidak memenuhi kebutuhan masyarakat perlu diganti dengan yang baru, yang merupakan salah satu pertimbangan pokok dalam pembentukan peraturan perundang-undangan (khususnya dalam bentuk undang-undang), misalnya dalam pembentukan Undang-Undang Nomor 28 Tahun 2014 tentang Hak Cipta (selanjutnya disebut UUHC), pada konsiderans (dasar pertimbangan) huruf $d$ undang-undang tersebut, disebutkan bahwa Undang-Undang Nomor 19 Tahun 2002 tentang Hak Cipta sudah tidak sesuai dengan perkembangan hukum dan kebutuhan masyarakat sehingga perlu diganti dengan undang-undang yang baru.

Undang-Undang Nomor 19 Tahun 2002 tentang Hak Cipta yang menurut pembentuk undang-undang sudah tidak sesuai dengan perkembangan hukum dan kebutuhan masyarakat sehingga perlu diganti dengan undang-undang yang baru (UUHC), tentunya memiliki dampak dalam rangka penegakan hukum di bidang hak cipta itu sendiri. Dampak

1 C.S.T. Kansil dan Christine S.T. Kansil, Latihan Ujian: Pengantar Hukum Indonesia (Jakarta: Sinar Grafika, 2007).

2 Hasim Purba, Pengantar IImu Hukum Indonesia (Medan: Fakultas Hukum Universitas Sumatera Utara, 2007). tersebut tentunya sangat perlu dipahami oleh seluruh masyarakat karena menurut substansi-nya, UUHC tidak hanya mengatur ketentuan mengenai hukum privat akan tetapi juga memuat ketentuan mengenai hukum publik.

Substansi UUHC, meliputi aspek Hukum Privat dan Hukum Publik. Oleh karena itu, dalam tulisan ini hanya dilakukan kajian terhadap unsur hukum publik dari undang-undang tersebut khususnya terkait kriminalisasi dan dekriminalisasi. Hal ini sangat penting karena kriminalisasi dan dekriminalisasi berkaitan erat dengan dapat atau tidaknya seseorang dinyatakan melakukan perbuatan melawan hukum menurut hukum pidana sebagai bagian dari hukum publik.

Menurut Jimly Asshiddiqie, tidaklah adil untuk memaksakan berlaku sesuatu norma hukum kepada mereka yang sama sekali tidak mengerti, tidak terlibat, dan tidak terjangkau pengetahuannya tentang norma aturan yang diberlakukan itu kepadanya. Jika dalam norma aturan itu terjadi proses kriminalisasi, sudah tentu orang yang bersangkutan terancam menjadi kriminal tanpa ia sendiri menyadarinya. Oleh karena itu, di samping adanya dan di antara kegiatan pembuatan hukum (law making) dan penegakan hukum (law enforcing), diperlukan kegiatan, yaitu pemasyarakatan hukum (law socialization) yang cenderung diabaikan dan dianggap tidak penting selama ini. Padahal, inilah kunci tegaknya hukum. Tanpa basis sosial yang menyadari hak dan kewajibannya secara hukum, maka hukum apapun yang dibuat tidak akan efektif, tidak akan tegak, dan tidak akan ditaati dengan sungguh-sungguh. ${ }^{3}$

Penulis meyakini bahwa dengan adanya kemampuan subjek hukum untuk mengungkap semua hal yang terkait dengan kriminalisasi dan dekriminalisasi di bidang

3 Jimly Asshiddiqie, Konstitusi dan Konstitusionalisme Indonesia (Jakarta: Konstitusi Press, 2005). 
(penegakan) hukum, akan membawa manfaat bagi subjek hukum tersebut - di antaranya adalah lepas dari jeratan hukum dan lebih menghargai suatu ciptaan (dalam konteks Hak Cipta). Oleh karena itu, penelitian ini merupakan "salah satu upaya" dalam mengungkap semua hal terkait kriminalisasi dan dekriminalisasi tersebut. Dinyatakan sebagai "salah satu upaya" yang disebabkan oleh terbatasnya ruang lingkup penelitian ini, yaitu hanya terbatas di bidang Hak Cipta.

Unsur pokok kriminalisasi di dalam UUHC adalah penggunaan ciptaan dari pencipta atau pemegang hak cipta secara komersial, yaitu pemanfaatan ciptaan dan/atau produk hak terkait dengan tujuan untuk memperoleh keuntungan ekonomi dari berbagai sumber atau berbayar. Dengan demikian, setiap subjek hukum yang tanpa izin pencipta atau pemegang hak cipta seharusnya dikenakan pidana apabila melakukan penggandaan dan/atau penggunaan secara komersial suatu ciptaan. Akan tetapi, pada banyak peristiwa hukum, negara tidak memberi "penderitaan" kepada para pengguna suatu ciptaan orang lain untuk tujuan komersial. Hal ini (kemudian) diperparah dengan politik hukum negara, yaitu mengklasifikasikan delik atau pelanggaran hukum pidana di bidang hak cipta sebagai delik aduan berdasarkan UUHC.

Salah satu contoh peristiwa hukum yang penulis maksud di atas, khususnya di bidang akademis adalah tindakan memperjualbelikan buku ajar dan/atau buku teks perguruan tinggi yang substansinya berasal dari suatu hasil penelitian.

Menurut penulis, ${ }^{4}$ adalah tindakan yang

4 Pada beberapa kesempatan, penulis (dalam kapasitas sebagai pemilik usaha Penerbitan Buku Hawa dan AHWA), mungkin telah memberikan "rasa kecewa" kepada beberapa rekan sejawat yang ingin melakukan penjualan terhadap laporan hasil penelitiannya yang telah dimodifikasi dan diharapkan menjadi buku yang ber-ISBN. Akan tetapi, penulis berusaha untuk membunuh "rasa kecewa" mereka yang pada pokoknya menyatakan legal apabila suatu hasil penelitian memuat (dan sudah seharusnya) berisikan banyak sumber kutipan karena luaran atau produk akhirnya hanya berupa laporan penelitian yang tidak dikomersialkan (misalnya karya ilmiah dalam bentuk Skripsi, Tesis, Disertasi, dan lain sebagainya - seperti artikel ini misalnya).

Sebaliknya, penulis berpendapat bahwa adalah tindakan yang ilegal apabila laporan penelitian tersebut di atas, dikomersialkan pada toko buku tertentu, baik dalam skala nasional maupun internasional, dan baik itu dipasarkan di dunia nyata maupun di dunia maya. Hal ini pada akhirnya membuat penulis memiliki pendapat yang sama dengan apa yang dinyatakan oleh Taufik $\mathrm{H}$. Simatupang, ${ }^{5}$ yang pada intinya berdasarkan lembagalembaga internasional yang bergerak di bidang kekayaan intelektual, Indonesia ditempatkan sebagai "priority watch list" karena masih rendahnya perlindungan terhadap kekayaan intelektual. Selain itu, hal tersebut juga didasarkan atas hasil jajak pendapat $\mathrm{DJKI}^{6}$ (2011) tentang rendahnya

selama tidak untuk diperjualbelikan, penulis bersedia menerbitkan karya ilmiahnya tersebut ke dalam bentuk buku. Apakah penulis berhasil membunuh rasa itu? Jawaban atas pertanyaan ini memiliki beberapa dimensi dan tentu saja ada tidak dapat dielakkan perbedaan pendapat antara penulis dengan para rekan sejawat tersebut. Salah satu "luaran" yang nyata dari perbedaan pendapat tersebut adalah timbulnya terminologi "ganti biaya cetak".

5 Taufik H. Simatupang, "Sistem Hukum Perlindungan Kekayaan Intelektual dalam Rangka Meningkatkan Kesejahteraan Masyarakat (Law System of Intellectual Property Protection in Order to Improve People Prosperity)," Jurnal Penelitian Hukum DE JURE 17, No. 2 (2017): 195-208.

6 DJKI adalah akronim dari Direktorat Jenderal Kekayaan Intelektual. Direktorat ini adalah unit utama di lingkungan Kementerian Hukum dan HAM yang mempunyai tugas dan fungsi merumuskan dan melaksanakan kebijakan dan standarisasi teknis di bidang kekayaan intelektual, dari mulai pendaftaran, perlindungan, pengawasan, penyelesaian sengketa, promosi hingga pengaduan tentang kekayaan intelektual. Selengkapnya lihat: Trisapto Wahyudi Agung Nugroho, "Analisis E-Government terhadap 
kesadaran HKI masyarakat.

Tentunya adalah kajian yang menarik mengenai pertanggungjawaban pidana dari para pihak yang terlibat dalam "aksi tidak sportif" sebagaimana yang telah diuraikan sebelumnya. Akan tetapi, kajian tersebut tidak menjadi pokok dari artikel ini - melainkan hanya sebagai uraian pembuka bahwa kriminalisasi (dan dekriminalisasi) di bidang hak cipta harus dipahami oleh setiap warga negara ditinjau dari aspek politik hukum yang melatarbelakanginya. Meskipun demikian, sebagai bahan perenungan bersama dalam konteks "aksi tidak sportif" tersebut, penulis meminta para pembaca untuk memberikan penafsiran terhadap ketentuan yang diatur pada Pasal 9 Ayat (3) UUHC.

Pasal 9 Ayat (3) UUHC pada pokoknya menegaskan ketentuan bahwa setiap orang yang tanpa izin pencipta atau pemegang hak cipta dilarang melakukan penggandaan dan/ atau penggunaan secara komersial ciptaan. Akan tetapi, di dalam UUHC itu sendiri, tidak diatur sanksi hukum (baik yang bersifat pidana, perdata, atau administrasi) terkait dengan apabila terjadi pelanggaran hukum atas Pasal 9 Ayat (3) UUHC tersebut. Hal ini menurut penulis adalah salah satu bentuk kelemahan politik hukum negara Indonesia dalam konteks kriminalisasi di bidang hukum atas kekayaan intelektual, khususnya di bidang hak cipta.

Penelitian tentang kriminalisasi di bidang hak cipta sudah banyak dilakukan. Akan tetapi, hal itu tidak sebanding dengan penelitian tentang dekriminalisasi di bidang hak cipta yang masih minim kajiannya secara ilmiah. Oleh karena itu, penulis meyakini bahwa kajian dekriminalisasi dalam artikel ini adalah suatu hal yang patut untuk dikonsumsi oleh para pembaca.

Pelayanan Publik di Kementerian Hukum dan HAM (Analysis of E-Government to Public Services in the Ministry of Law and Human Rights)," JIKH 10, No. 3 (2016): 279-296.
Berdasarkan hasil penelitian Ari Wibowo, yaitu sebelum UUHC diberlakukan, disebutkan bahwa tampak ketidakkonsistenan pembuat undang-undang karena ketentuan undangundang $\mathrm{HKI}$ selain hak cipta, semuanya menentukan bahwa tindak pidananya sebagai delik aduan. ${ }^{7}$ Hanya saja dalam hasil penelitian tersebut, tidak dijelaskan politik hukum yang melalatarbelakangi terjadinya hal tersebut. Oleh karena itu, penelitian ini secara khusus memberikan gambaran tentang politik hukum yang melalatarbelakangi kriminalisasi dan dekriminalisasi di bidang hak cipta pasca penetapan UUHC.

\section{Rumusan Masalah}

Penelitian ini dilandasi oleh keingintahuan dalam mengungkap dasar pemikiran terhadap bentuk-bentuk kriminalisasi dan dekriminalisasi di bidang hak cipta untuk mencapai tujuan bahwa setiap orang harus mengetahui batasan-batasan terhadap suatu perbuatan yang dapat dipidana, khususnya dalam aspek hak cipta dan faktor yang mempengaruhinya. Oleh karena itu, dalam penelitian ini dirumuskan masalah sebagai berikut: Pertama, apa saja dasar pemikiran proses kriminalisasi ditinjau dari pembentukan UUHC? Kedua, apa saja dasar pemikiran proses dekriminalisasi ditinjau dari pembentukan UUHC?

\section{Tujuan}

Penelitian ini bertujuan untuk mengetahui dan menganalisis dasar pemikiran proses kriminalisasi ditinjau dari pembentukan UUHC serta untuk mengetahui dan menganalisis dasar pemikiran proses dekriminalisasi ditinjau dari pembentukan UUHC.

Kontribusi penelitian ini terhadap ilmu pengetahuan, khususnya ilmu pengetahuan

$7 \quad$ Ari Wibowo, "Justifikasi Hukum Pidana terhadap Kebijakan Kriminalisasi Pelanggaran Hak Cipta, serta Perumusan Kualifikasi Yuridis dan Jenis Deliknya," Jurnal Hukum Ius Quia Iustum 22, No. 1 (2015): 54-75. 
hukum adalah memberikan suatu pemahaman bahwa hukum buatan manusia akan senantiasa berubah (dinamis) sampai manusia itu menyadari bahwa hanya dengan hukum ciptaan Sang Maha Pencipta akan tercapai suatu tatanan hukum yang bersifat statis tanpa melibatkan unsur-unsur politis.

\section{Metode Penelitian}

Metode penelitian yang digunakan dalam penelitian ${ }^{8}$ ini adalah metode penelitian hukum normatif. Jenis data ${ }^{9}$ yang digunakan di dalam penelitian ini adalah data sekunder yang disajikan secara kualitatif. Data sekunder dalam penelitian ini terdiri dari bahan hukum primer, ${ }^{10}$ yang bersumber dari peraturan perundang-undangan dan putusan pengadilan; bahan hukum sekunder

8 Menurut Roeslan Saleh, dalam bukunya: "Dari Lembaran Kepustakaan Hukum Pidana", setiap peneliti tunduk kepada tiga subjektifitas, yaitu subjektifitas dari masanya, kelompoknya, dan dirinya sendiri. Jika pun mungkin membuat terang dua subjektifitas yang tersebut terakhir, namun masih belum mungkin untuk memecahkan subjektifitas yang pertama, yaitu subjektifitas dari masa atau waktu. Selengkapnya lihat: Duwi Handoko, "Pemidanaan terhadap Kejahatan Tanpa Korban berdasarkan Putusan Kasasi Tahun 2007-2012 (Analisis Yuridis terhadap Tindak Pidana Perjudian)" (Universitas Islam Riau, 2013).

9 Menurut Andi Hamzah dalam bukunya: "Hukum Pidana yang berkaitan dengan Komputer", disebutkan bahwa yang dimaksud dengan data adalah bahan yang akan diolah menjadi bentuk yang lebih mempunyai arti. Selengkapnya lihat: lbid.

10 Menurut Soerjono Soekanto dan Sri Mamudji, bahan hukum primer adalah bahan-bahan hukum yang mengikat, seperti Undang-Undang Dasar Tahun 1945, peraturan perundang-undangan, hukum adat, yurisprudensi, dan sebagainya. Bahan hukum sekunder, yang memberikan penjelasan mengenai bahan hukum primer, seperti, rancangan undang-undang, hasil-hasil penelitian, hasil karya dari kalangan hu-kum, dan seterusnya. Sedangkan bahan hukum tertier adalah bahan yang memberikan petunjuk maupun penjelasan terhadap bahan hukum primer dan sekunder, contohnya adalah kamus, ensiklopedia, indeks kumulatif, dan seterusnya. Selengkapnya lihat: Soerjono Soekanto dan Sri Mamudji, Penelitian Hukum Normatif (Jakarta: RajaGrafindo Persada, 2007). yang bersumber dari buku-buku; dan bahan hukum tersier sebagai bahan penunjang dari bahan hukum primer dan bahan hukum sekunder. Pola pendekatan masalah yang digunakan di dalam penelitian adalah dengan menggunakan statute approach (pendekatan dari aspek aturan hukum), conceptual approach (pendekatan dari aspek konsep atau teori hukum) dan comparative approach (pendekatan dari aspek perbandingan). Teknik pengumpulan data dilakukan dengan cara studi kepustakaan, yaitu menghimpun semua data tertulis yang terkait dengan objek penelitian.

\section{PEMBAHASAN}

Dasar Pemikiran Proses Kriminalisasi Ditinjau dari Pembentukan UUHC

Padmo Wahjono menyatakan, politik hukum adalah kebijakan penyelenggara negara tentang apa yang dijadikan kriteria untuk menghukumkan sesuatu yang di dalamnya mencakup pembentukan, penerapan, dan penegakan hukum. ${ }^{11}$

Politik hukum menurut Moh. Mahfud MD adalah legal policy atau arah hukum yang akan diberlakukan oleh negara untuk mencapai tujuan negara yang bentuknya dapat berupa pembuatan hukum baru dan penggantian hukum lama. ${ }^{12}$

Kebijakan hukum pidana dalam bahasa Inggris disebut dengan penal policy. Istilah "policy" sering diterjemahkan dalam bahasa Indonesia dengan kata "politik", oleh karena itu berbicara politik hukum pidana tidak terlepas dari pembicaraan mengenai politik hukum secara keseluruhan karena hukum pidana adalah salah satu bagian dari ilmu hukum. ${ }^{13}$

\footnotetext{
11 Moh. Mahfud MD, Politik Hukum di Indonesia (Jakarta: Rajawali Pers, 2010).

12 Moh. Mahfud MD, Membangun Politik Hukum Menegakkan Konstitusi (Jakarta: Rajawali Pers, 2011).

13 Irwan Jasa Tarigan, Narkotika dan Penang-
} 
Marc Ancel menyatakan politik hukum pidana merupakan suatu ilmu sekaligus seni dengan tujuan praktis untuk memungkinkan peraturan hukum positif dirumuskan secara lebih baik dan untuk memberi pedoman kepada pembuat undang-undang, pengadilan yang menerapkan undang-undang dan kepada para pelaksana putusan pengadilan. ${ }^{14}$

Ruang lingkup politik hukum pidana menurut A. Mulder adalah: Pertama, seberapa jauh ketentuan-ketentuan pidana yang berlaku perlu dilakukan perubahan atau diperbaharui. Kedua, apa yang dapat diperbuat untuk mencegah terjadinya kejahatan. Ketiga, cara bagaimana penyidikan, penuntutan, peradilan dan pelaksanaan pidana harus dilaksanakan. ${ }^{15}$

Kriminalisasi di bidang hak cipta sebagai bagian dari Politik Hukum Pidana Indonesia, ${ }^{16}$ menurut penulis adalah kehendak penguasa negara mengenai hukum pidana yang berlaku dan mengenai arah perkembangan hukum pidana yang dibangun, khususnya di bidang hak cipta. Kehendak penguasa negara tersebut dapat diartikan sebagai kekuasaan yang berwenang membentuk peraturan perundang-undangan, ${ }^{17}$ baik dalam bentuk

gulangannya (Yogyakarta: Deepublish, 2017).

14 Fernandes Edy Syahputra, L. Erwina Silaban, dan Mahmud Mulyadi, "Kebijakan Hukum Pidana terhadap Pengaturan Tindak Pidana Narkotika di Indonesia," Jurnal Mahupiki (2012).

15 Tarigan, Narkotika Dan Penanggulangannya.

16 Politik hukum memiliki dua aspek, yaitu ius constituendum dan ius constitutum. Selengkapnya lihat: Imam Syaukani dan A. Ahsin Thohari, Dasardasar Politik Hukum (Jakarta: Rajawali Pers, 2010).

17 Berdasarkan Pasal 1 angka 2 Undang-Undang Nomor 12 Tahun 2011 tentang Pembentukan Peraturan Perundang-undangan, yang dimaksud dengan peraturan perundang-undangan adalah peraturan tertulis yang memuat norma hukum yang mengikat secara umum dan dibentuk atau ditetapkan oleh lembaga negara atau pejabat yang berwenang melalui prosedur yang ditetapkan dalam peraturan perundangundangan. Selengkapnya lihat: Undang-Undang Nomor 12 Tahun 2011 tentang Pembentukan Peraturan Perundang-Undangan (Republik Indonesia, 2011). undang-undang maupun dalam bentuk regulasi lainnya.

Terjadinya proses kriminalisasi (dan dengan atau tanpa diiringi proses dekriminalisasi) di bidang hak cipta, secara tidak langsung menegaskan bahwa politik hukum pidana terkait hak cipta senantiasa berubah-ubah. Perubahan-perubahan tersebut dapat ditinjau dari diberlakukannya peraturan yang baru untuk menggantikan peraturan yang lama. Undang-undang tentang hak cipta yang pertama kalinya diberlakukan di Indonesia adalah Auteurswet 1912 sampai akhirnya pada saat pelaksanaan penelitian ini, undang-undang yang berlaku adalah UUHC.

Secara singkat, dibawah ini diuraikan dasar pemikiran dan implementasi politik hukum pidana mengenai hak cipta di Indonesia dari aspek yang menarik untuk dicermati, yaitu kriminalisasi dan dekriminalisasi. Namun, sebelum menguraikan aspek tersebut, disajikan dahulu undang-undang tentang hak cipta yang pernah berlaku dan yang berlaku saat ini di Indonesia (Gambar 1) disertai dengan jangka waktu berlakunya (Tabel 1) dan faktor-faktor yang mempengaruhi politik hukum pidana terkait hak cipta di Indonesia (Tabel 2).

\section{Gambar 1}

Sejarah Undang-Undang tentang Hak Cipta di Indonesia

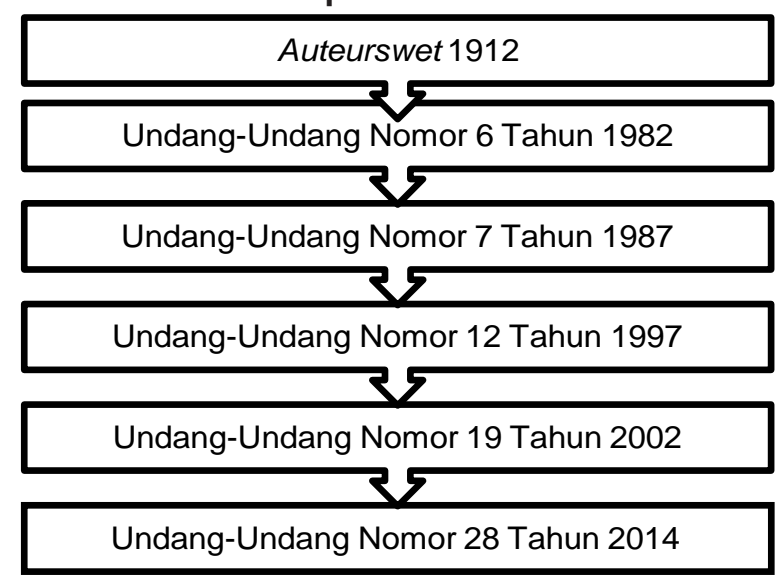

Sumber: Duwi Handoko, Hukum Positif mengenai Hak Kekayaan Intelektual di Indonesia (Jilid I), Pekanbaru: Hawa dan AHWA, 2015. 
Tabel 1

Jangka Waktu Berlaku Undang-Undang tentang Hak Cipta di Indonesia

\begin{tabular}{|c|c|c|c|}
\hline No. & $\begin{array}{l}\text { Undang-Undang } \\
\text { tentang Hak Cipta yang } \\
\text { Pernah Berlaku dan } \\
\text { yang Berlaku Saat ini di } \\
\text { Indonesia }\end{array}$ & $\begin{array}{l}\text { Berlaku } \\
\text { dan } \\
\text { Dicabut } \\
\text { pada } \\
\text { Tanggal }\end{array}$ & $\begin{array}{l}\text { Jangka } \\
\text { Waktu } \\
\text { Berlaku } \\
\text { (Tahun) }\end{array}$ \\
\hline 1 & Auteurswet 1912 & $\begin{array}{l}\text { April } \\
1913-12 \\
\text { April } 1982\end{array}$ & 69 \\
\hline 2 & $\begin{array}{l}\text { Undang-Undang Nomor } \\
6 \text { Tahun } 1982 \text { beserta } \\
\text { Perubahannya (Undang- } \\
\text { Undang Nomor } 7 \text { Tahun } \\
1987 \text { dan Undang- } \\
\text { Undang Nomor } 12 \text { Tahun } \\
\text { 1997) }\end{array}$ & $\begin{array}{l}12 \text { April } \\
1982-29 \\
\text { Juli } 2003\end{array}$ & 21 \\
\hline 3 & $\begin{array}{l}\text { Undang-Undang Nomor } \\
19 \text { Tahun } 2002\end{array}$ & $\begin{array}{l}29 \text { Juli } \\
2003 \text { - } \\
16 \text { Oktober } \\
2014\end{array}$ & 11 \\
\hline 4 & $\begin{array}{l}\text { Undang-Undang Nomor } \\
28 \text { Tahun } 2014\end{array}$ & $\begin{array}{l}16 \text { Oktober } \\
2014 \text { - } \\
\text { Belum } \\
\text { Dicabut }\end{array}$ & $\begin{array}{l}\text { Masih } \\
\text { Berlaku } \\
\text { pada } \\
\text { Saat ini }\end{array}$ \\
\hline
\end{tabular}

Sumber: Duwi Handoko, Hukum Positif mengenai Hak Kekayaan Intelektual di Indonesia (Jilid I), Pekanbaru: Hawa dan AHWA, 2015.
Tabel 2

Faktor-faktor yang Mempengaruhi Politik Hukum Pidana Terkait Hak Cipta di Indonesia

\begin{tabular}{|c|c|c|}
\hline No. & Indikator & Uraian Singkat \\
\hline 1 & $\begin{array}{l}\text { Melakukan } \\
\text { Pemba- } \\
\text { ngunan } \\
\text { di Bidang } \\
\text { Hukum }\end{array}$ & $\begin{array}{ll}\text { a. } & \text { Menyesuaikan dengan } \\
& \text { perkembangan teknologi } \\
& \text { informasi dan komunikasi. } \\
\text { b. } & \text { Efektivitas pembangunan hukum } \\
& \text { ditinjau dari perkembangan } \\
& \text { kehidupan yang berlangsung } \\
& \text { cepat, terutama di bidang } \\
& \text { perekonomian baik di tingkat } \\
& \text { nasional maupun internasional. } \\
& \text { Antara lain ekonomi kreatif. } \\
\text { c. } & \text { Mendorong dan melindungi } \\
& \text { penciptaan, penyebarluasan hasil } \\
& \text { karya ilmu, seni dan sastra. } \\
\text { d. } & \text { Mempercepat pertumbuhan dan } \\
& \text { kecerdasan kehidupan bangsa. } \\
\text { e. } & \text { Memperhatikan keseimbangan } \\
& \text { antara kepentingan pencipta, } \\
& \text { pemegang hak cipta, atau pemilik } \\
& \text { hak terkait, dengan } \\
\text { masyarakat serta memperhatikan } & \text { ketentuan dalam perjanjian atau } \\
\text { persettujuan internasional di } \\
\text { bidang hak cipta dan hak terkait. } \\
\text { f. Pengaturan yang proporsional } \\
\text { sangat diperlukan, agar fungsi } \\
\text { positif hak cipta (kesejahteraan } \\
\text { rakyat) dapat dioptimalkan dan } \\
\text { dampak negatifnya (kejahatan) } \\
\text { dapat diminimalkan. }\end{array}$ \\
\hline
\end{tabular}




\begin{tabular}{|c|c|c|c|}
\hline 2 & $\begin{array}{l}\text { Pemberian } \\
\text { Perlindungan } \\
\text { Hukum }\end{array}$ & $\begin{array}{l}\text { e. } \\
\text { f. }\end{array}$ & $\begin{array}{l}\text { Mewujudkan iklim yang lebih baik } \\
\text { bagi tumbuh dan berkembangnya } \\
\text { gairah mencipta di bidang ilmu } \\
\text { pengetahuan, seni, dan sastra. } \\
\text { Pengakuan negara terhadap } \\
\text { karya cipta seorang pencipta } \\
\text { sehingga diharapkan membawa } \\
\text { pertumbuhan ekonomi } \\
\text { kreatif secara signifikan dan } \\
\text { memberikan kontribusi nyata bagi } \\
\text { perekonomian dan kesejahteraan } \\
\text { rakyat. } \\
\text { Jangka waktu perlindungan } \\
\text { terhadap ciptaan. } \\
\text { Perlindungan terhadap hak cipta } \\
\text { asing. } \\
\text { Lisensi hak cipta. } \\
\text { Hak ekonomi (economic rights) } \\
\text { dan hak moral (moral rights) di } \\
\text { bidang Hak Cipta. Teringkarinya } \\
\text { hak ekonomi dan hak moral } \\
\text { dapat mengikis motivasi para } \\
\text { pencipta dan pemilik hak terkait } \\
\text { untuk berkreasi. Hilangnya } \\
\text { motivasi seperti ini akan } \\
\text { berdampak luas pada runtuhnya } \\
\text { kreativitas makro bangsa. } \\
\text { Perlindungan tidak diberikan } \\
\text { kepada ide atau gagasan karena } \\
\text { karya cipta harus memiliki bentuk } \\
\text { yang khas, bersifat pribadi dan } \\
\text { menunjukkan keaslian sebagai } \\
\text { ciptaan yang lahir berdasarkan } \\
\text { kemampuan, kreativitas, atau } \\
\text { keahlian sehingga ciptaan } \\
\text { itu dapat dilihat, dibaca, atau } \\
\text { didengar. }\end{array}$ \\
\hline
\end{tabular}

\begin{tabular}{|c|c|c|c|}
\hline 3 & $\begin{array}{l}\text { Mengatasi } \\
\text { dan } \\
\text { Menghentikan } \\
\text { Pelanggaran } \\
\text { Hak Cipta }\end{array}$ & b. & $\begin{array}{l}\text { Rendahnya tingkat pemahaman } \\
\text { masyarakat akan arti dan fungsi } \\
\text { terhadap hak cipta. Oleh karena } \\
\text { itu, diperlukan penyuluhan hukum } \\
\text { yang luas dan intensif untuk } \\
\text { menyebarluaskan pemahaman } \\
\text { kepada masyarakat akan arti dan } \\
\text { fungsi dari hak cipta. } \\
\text { Sikap dan keinginan untuk } \\
\text { memperoleh keuntungan dagang } \\
\text { dengan cara yang mudah. } \\
\text { Belum cukup terbinanya } \\
\text { kesamaan pengertian, sikap, dan } \\
\text { tindakan para aparat penegak } \\
\text { hukum dalam menghadapi } \\
\text { pelanggaran hak cipta. Oleh } \\
\text { karena itu, diperlukan upaya } \\
\text { untuk menyamakan pemahaman } \\
\text { mengenai masalah hak cipta di } \\
\text { kalangan aparat penegak hukum. } \\
\text { Sebab, efektivitas penindakan } \\
\text { hukum terhadap pelanggaran hak } \\
\text { cipta pada akhirnya juga sangat } \\
\text { dipengaruhi oleh kesamaan } \\
\text { pemahaman, sikap, dan tindakan } \\
\text { di antara aparat penegak hukum. } \\
\text { Pengangkatan Pejabat } \\
\text { Pegawai Negeri Sipil Tertentu } \\
\text { sebagai penyidik dalam rangka } \\
\text { penanggulangan pelanggaran } \\
\text { hak cipta. } \\
\text { Telah berkembang kegiatan } \\
\text { terhadap hak cipta. } \\
\text { pelanggaran hak cipta, terutama } \\
\text { dalam bentuk tindak pidana } \\
\text { pembajakan lagu atau musik, } \\
\text { buku dan penerbitan, film dan } \\
\text { rekaman video, serta program } \\
\text { komputer. } \\
\text { Pembajakan telah mencapai } \\
\text { tingkat yang membahayakan } \\
\text { dan dapat merusak tatanan } \\
\text { kehidupan masyarakat pada } \\
\text { umumnya dan minat untuk } \\
\text { mencipta pada khususnya. } \\
\text { Pembajakan membahayakan } \\
\text { pelam arti } \\
\text { penaanan }\end{array}$ \\
\hline
\end{tabular}




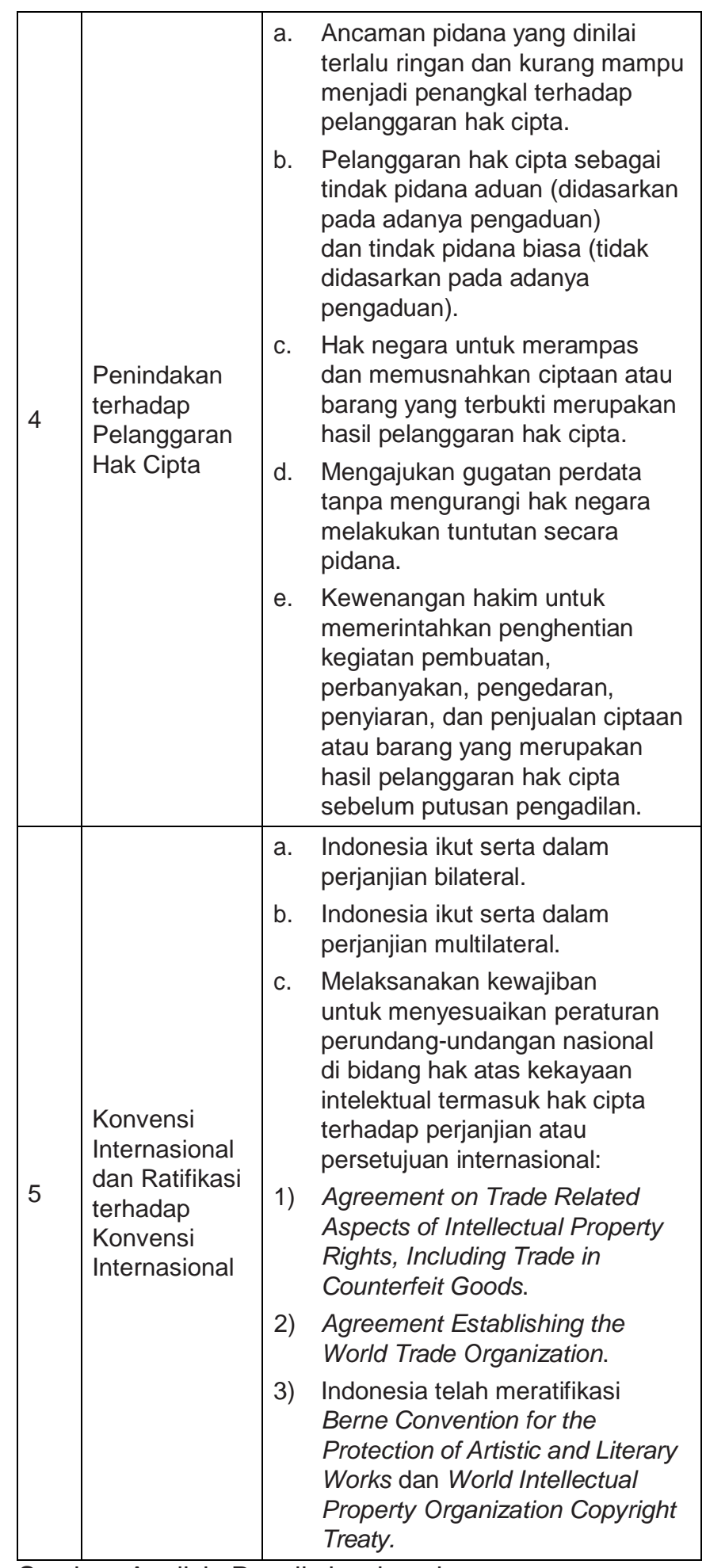

Sumber: Analisis Penulis berdasarkan

Pemberlakuan Undang-Undang tentang Hak

Cipta Sesudah Indonesia Merdeka.

Ditinjau dari substansi undang-undang hak cipta yang memuat ketentuan pidana, maka perubahan undang-undang tentang hak cipta sebagaimana diuraikan di atas tentunya tidak bisa dilepaskan dari politik hukum pidana yang melatarbelakanginya atau dengan kata lain tidak bisa dilepaskan dari kebijakan kriminal dengan menggunakan sarana penal.

Dua masalah sentral dalam kebijakan kriminal dengan menggunakan sarana penal (hukum pidana) ialah masalah penentuan terhadap perbuatan apa yang seharusnya dijadikan tindak pidana, dan sanksi apa yang sebaiknya digunakan atau dikenakan kepada si pelanggar. Melakukan analisis terhadap dua masalah sentral ini tidak dapat dilepaskan dari konsepsi integral antara kebijakan kriminal dengan kebijakan sosial atau kebijakan pembangunan nasional. Masalah sentral mengenai perbuatan apa yang seharusnya dijadikan tindak pidana sering disebut dengan masalah kriminalisasi. ${ }^{18} \mathrm{Hal}$ tersebut secara singkat diuraikan pada gambar di bawah ini.

\section{Gambar 2}

\section{Cabang dan Cakupan Politik Hukum Pidana}

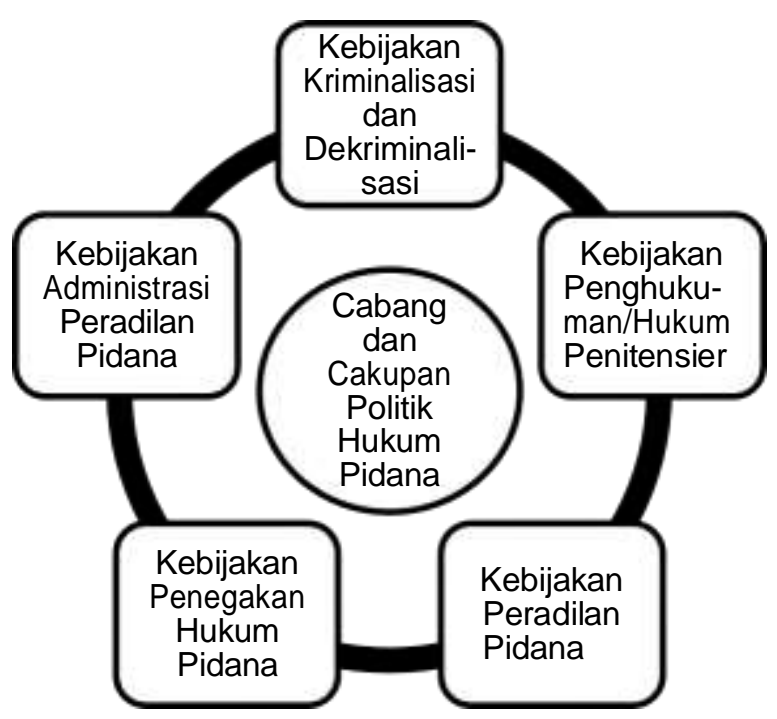

Sumber: Analisis Penulis, 2019.

Kebijakan kriminalisasi merupakan suatu kebijakan dalam menetapkan suatu perbuatan yang semula bukan tindak pidana (tidak dipidana) menjadi suatu tindak pidana

18 Barda Nawawi Arief, Bunga Rampai Kebijakan Hukum Pidana: (Perkembangan Penyusunan Konsep KUHP Baru) (Jakarta: Kencana, 2011). 
(perbuatan yang dapat dipidana). Jadi, pada hakikatnya kriminalisasi merupakan bagian dari kebijakan kriminal (criminal policy) dengan menggunakan sarana hukum pidana (penal), dan oleh karena itu termasuk bagian dari kebijakan hukum pidana (penal policy). ${ }^{19}$

Dalam praktek pembentukan peraturan perundang-undangan selama ini tidak dibicarakan secara terpisah mengenai dasar-dasar pertimbangan mengapa suatu perbuatan itu dijadikan tindak pidana dan dasar-dasar pertimbangan mengapa perbuatan itu perlu ditanggulangi dengan sanksi pidana. Jadi seolah-olah merupakan hal yang wajar apabila suatu perbuatan sudah ditetapkan sebagai tindak pidana kemudian secara begitu saja ditetapkan sanksi pidananya. ${ }^{20}$

Penetapan suatu perbuatan menjadi suatu tindak pidana (kriminalisasi) tergantung politik hukum pembentuk undang-undang. Proses kriminalisasi suatu perbuatan tidak jarang menjadi perdebatan yang ramai dibicarakan di tengah masyarakat. ${ }^{21}$ Oleh karena itu, sudah tepat apabila Ifdal Kasim, mengartikan politik hukum pidana sebagai suatu kebijakan, baik untuk memberikan penilaian ke atas suatu kelakuan manusia sebagai kelakuan jahat atau bukan jahat; yang oleh Ifdal Kasim disebut melakukan kriminalisasi (criminalization) maupun dekriminalisasi (decriminalization) terhadap suatu kelakuan atau perbuatan. ${ }^{22}$

Politik hukum pidana dapat dibagikan dalam beberapa bentuk cabang dan cakupan, salah satunya kebijakan kriminalisasi (criminalization policy), yaitu politik hukum

19 Barda Nawawi Arief, Kapita Selekta Hukum Pidana (Bandung: Citra Aditya Bakti, 2003).

20 Barda Nawawi Arief, Kebijakan Legislatif dalam Penanggulangan Kejahatan dengan Pidana Penjara (Yogyakarta: Genta Publishing, 2010).

21 Erdianto Effendi, Hukum Pidana Indonesia - Suatu Pengantar (Bandung: Refika Aditama, 2011).

22 J.E. Sahetapy, Problematika Pembaruan Hukum Pidana Nasional (Jakarta: Komisi Hukum Nasional $\mathrm{RI}, 2013)$. yang fokus pada usaha memformulasikan perbuatan jahat sebagai tindak pidana yang diperbaharui atau bentuk perumusan yang baru dalam perancangan undangundang, seperti pembuatan RUU KUHP atau tindak pidana tertentu. Termasuk dalam politik hukum ini, adalah kebijakan yang berkaitan dengan penghapusan perbuatan yang semula sebagai tindak pidana dalam undang-undang menjadi bukan tindak pidana (decriminalization). ${ }^{23}$

Kriminalisasi sebagaimana diatur di dalam Pasal 112 UUHC menurut hemat penulis bukan merupakan kriminalisasi murni, ${ }^{24}$ karena substansi pada Pasal 112 tersebut sudah pernah diatur dalam Pasal 72 Ayat (6), Pasal 72 Ayat (7), dan Pasal 72 Ayat (8) Undang-Undang Nomor 19 Tahun 2002 tentang Hak Cipta.

Kriminalisasi sebagaimana diatur di dalam Pasal 113 UUHC menurut hemat penulis juga bukan merupakan kriminalisasi murni yang dibentuk oleh pembentuk undangundang tersebut. Hal itu karena substansi pada Pasal 113 tersebut sudah pernah diatur dalam Pasal 72 Ayat (1) dan Pasal 72 Ayat (2) Undang-Undang Nomor 19 Tahun 2002 tentang Hak Cipta. Hanya saja, dalam pasal 72 Ayat (1) dan Pasal 72 Ayat (2) undangundang tersebut, semua tindakan hukum dapat dilakukan untuk pelanggaran hak cipta, baik untuk kepentingan komersial atau tidak untuk kepentingan komersial. Oleh karena

$23 \quad$ Ibid

24 Duwi Handoko, membagi pola dekriminalisasi dalam penegakan hukum di Indonesia ke dalam 4 (empat) bagian, yaitu dekriminalisasi bukan/ tidak murni, dekriminalisasi murni, dekriminalisasi murni sebahagian, dan dekriminalisasi bersyarat. Menurutnya, kriminalisasi murni diartikan sebagai kriminalisasi yang benar-benar baru diadakan oleh pembentukan undang-undang. Sedangkan, yang dimaksud dengan bukan kriminalisasi murni adalah kriminalisasi yang oleh pembentuk undangundang disadur dari kriminalisasi oleh pembentuk undang-undang sebelumnya. Selengkapnya lihat: Duwi Handoko, Dekriminalisasi terhadap Delikdelik dalam KUHP (Pekanbaru: Hawa dan AHWA, 2016). 
itu, karena pembentuk UUHC memuat unsur pokok berupa secara komersial, maka telah terjadi dekriminalisasi terhadap pelanggaran sebagaimana diatur di dalam Pasal 72 Ayat (1) dan Pasal 72 Ayat (2) Undang-Undang Nomor 19 Tahun 2002 tentang Hak Cipta.

Kriminalisasi sebagaimana diatur di dalam Pasal 114, Pasal 115, dan Pasal 119 UUHC menurut hemat penulis merupakan kriminalisasi murni oleh pembentuk undangundang tersebut. Hal itu karena substansi pada pasal-pasal tersebut belum pernah diatur dalam undang-undang mengenai hak cipta yang pernah berlaku sebelumnya di Indonesia.

Kriminalisasi sebagaimana diatur di dalam Pasal 116 dan Pasal 117 UUHC menurut hemat penulis bukan merupakan bentuk dari kriminalisasi murni yang dibentuk oleh pembentuk undang-undang tersebut. Hal itu karena substansi pada Pasal 116 tersebut sudah pernah diatur dalam Pasal 72 Ayat (1) Undang-Undang Nomor 19 Tahun 2002 tentang Hak Cipta.

Kriminalisasi sebagaimana diatur di dalam Pasal 118 UUHC menurut hemat penulis bukan merupakan bentuk dari kriminalisasi murni yang dibentuk oleh pembentuk undang-undang tersebut. Hal itu karena substansi Pasal 118 tersebut sudah pernah diatur dalam Pasal 72 Ayat (5) Undang-Undang Nomor 19 Tahun 2002 tentang Hak Cipta.

Ketentuan pidana sebagaimana diatur di dalam Pasal 120 UUHC menurut hemat penulis bukan merupakan bentuk dari kriminalisasi murni yang dibentuk oleh pembentuk undang-undang tersebut. Hal itu karena substansi pada Pasal 120 tersebut sudah pernah diatur dalam undang-undang mengenai hak cipta yang pernah berlaku sebelumnya di Indonesia, khususnya pada Pasal 45 Undang-Undang Nomor 6 Tahun 1982 tentang Hak Cipta.
Berdasarkan uraian di atas, terdapat "regulasi" dengan pola kriminalisasi murni dan bukan kriminalisasi murni oleh pembentuk UUHC. Kriminalisasi murni tersebut diatur pada Pasal 114; Pasal 115; dan Pasal 119. Sedangkan bukan kriminalisasi murni, diatur pada Pasal 112; Pasal 113; Pasal 116; Pasal 117; Pasal 118; dan Pasal 120. Hal ini, oleh Duwi Handoko, ${ }^{25}$ diuraikan sebagai berikut:

1. Kriminalisasi murni:

a. Pasal 114: Dasar pemikiran terhadap ketentuan pidana ini adalah pengelola tempat perdagangan bertanggung jawab atas tempat penjualan dan/atau pelanggaran hak cipta dan/atau hak terkait di pusat tempat perbelanjaan yang dikelolanya.

b. Pasal 115: Ketentuan pidana dalam Pasal 115 UUHC menekankan pada aspek penggunaan secara komersial. Hal ini berbeda dengan undang-undang tentang hak cipta yang berlaku sebelumnya, yaitu memuat ketentuan pidana bagi setiap orang tanpa mempedulikan apakah perbuatan yang terkait dengan potret, dilakukan untuk tujuan komersial secara bersyarat atau tidak.

c. Pasal 119: Salah satu unsur pokok dari rumusan tindak pidana pada pasal ini adalah penarikan royalti. Hal ini berarti pidana hanya dapat diterapkan kepada setiap lembaga manajemen kolektif yang tidak memiliki izin operasional dari menteri dan melakukan kegiatan penarikan royalti.

2. Bukan kriminalisasi murni:

a. Pasal 112: Salah satu unsur pokok dari rumusan tindak pidana pada Pasal 112 UUHC antara lain adalah penggunaan secara komersial.

25 Selengkapnya lihat: Duwi Handoko, Kriminali-sasi dan Dekriminalisasi di Bidang Hak Cipta (Pekanbaru: Hawa dan AHWA, 2015). 
Hal ini berarti pidana hanya dapat diterapkan kepada setiap orang yang dengan tanpa hak melakukan perbuatan menghilangkan, mengubah, atau merusak informasi manajemen hak cipta dan informasi elektronik hak cipta untuk penggunaan secara komersial.

b. Pasal 113: Salah satu unsur pokok dari rumusan tindak pidana, khususnya pada Pasal 113 Ayat (1) UUHC adalah penggunaan secara komersial. Hal ini berarti pidana hanya dapat diterapkan kepada setiap orang yang dengan tanpa hak melakukan pelanggaran hak ekonomi berupa menyewakan ciptaan untuk penggunaan secara komersial.

c. Pasal 116: Salah satu unsur pokok dari rumusan tindak pidana, khususnya pada Pasal 116 Ayat (1) UUHC adalah penggunaan secara komersial. Hal ini berarti pidana hanya dapat diterapkan kepada setiap orang yang dengan tanpa hak melakukan pelanggaran hak ekonomi berupa penyewaan atas fiksasi pertunjukan atau salinannya kepada publik untuk penggunaan secara komersial.

d. Pasal 117: Salah satu unsur pokok dari rumusan tindak pidana pada Pasal 117 Ayat (1) UUHC adalah penggunaan secara komersial. Hal ini berarti pidana hanya dapat diterapkan kepada setiap orang yang dengan sengaja dan tanpa hak melakukan pelanggaran hak ekonomi berupa menyewakan kepada publik atas salinan fonogram untuk penggunaan secara komersial. Salah satu unsur pokok dari rumusan tindak pidana pada Pasal 117 Ayat (2) UUHC adalah penggunaan secara komersial. Hal ini berarti pidana hanya dapat diterapkan kepada setiap orang yang dengan sengaja dan tanpa hak melakukan pelanggaran hak ekonomi berupa penggandaan atas fonogram dengan cara atau bentuk apapun, pendistribusian atas fonogram asli atau salinannya dan/atau penyediaan atas fonogram dengan atau tanpa kabel yang dapat diakses publik untuk penggunaan secara komersial. Salah satu unsur pokok dari rumusan tindak pidana pada Pasal 117 ayat (3) UUHC adalah pembajakan. Hal ini berarti pidana hanya dapat diterapkan kepada setiap orang yang dengan sengaja dan tanpa hak melakukan pelanggaran hak ekonomi berupa penggandaan atas fonogram dengan cara atau bentuk apapun, pendistribusian atas fonogram asli atau salinannya dan/atau penyediaan atas fonogram dengan atau tanpa kabel yang dapat diakses publik untuk penggunaan secara komersial dengan cara pembajakan.

e. Pasal 118: Salah satu unsur pokok dari rumusan tindak pidana pada Pasal 118 ayat (1) UUHC adalah penggunaan secara komersial. Hal ini berarti pidana hanya dapat diterapkan kepada setiap orang yang dengan sengaja dan tanpa hak melakukan pelanggaran hak ekonomi berupa penyiaran ulang siaran, komunikasi siaran, fiksasi siaran, dan/atau penggandaan fiksasi siaran untuk penggunaan secara komersial. Salah satu unsur pokok dari rumusan tindak pidana pada Pasal 118 Ayat (2) UUHC adalah pembajakan. Hal ini berarti pidana hanya dapat diterapkan kepada setiap orang yang dengan sengaja dan tanpa hak melakukan pelanggaran hak ekonomi berupa penggandaan fiksasi siaran untuk penggunaan secara komersial dengan maksud pembajakan. 
f. Pasal 120: Berdasarkan Pasal 120 UUHC, disebutkan bahwa: "Tindak pidana sebagaimana dimaksud dalam Undang-Undang ini merupakan delik aduan".

Terkait dengan dasar pemikiran yang menegaskan bahwa semua jenis tindak pidana dalam UUHC merupakan delik aduan, perlu diuraikan secara singkat di dalam penelitian ini mengenai hal tersebut sebagai bagian penutup dari pembahasan mengenai dasar pemikiran kriminalisasi di bidang hak cipta.

Hampir semua penulis hukum pidana (Sarjana Hukum Pidana), seperti Yonkers, Hazenwinkel Suringa, Pompe dan Van Hamel mengatakan bahwa alasan pembuat Kitab Undang-Undang Hukum Pidana (selanjutnya disebut KUHP) untuk memasukkan delik aduan (klacht delict) dalam sistematik ialah bahwa dalam beberapa hal, bagi yang bersangkutan (yang berhak mengadu/saksi pengadu) adalah lebih menguntungkan untuk tidak menuntut perkara itu dari pada keuntungan bagi pemerintah (masyarakat) jika dilakukan penuntutan perkara itu. ${ }^{26}$

Berdasarkan uraian mengenai landasan filosofis terhadap delik aduan di atas, uraian selanjutnya di bawah ini adalah mengenai dasar yuridis yang terkait dengan delik aduan sebagaimana yang ditetapkan di dalam KUHP maupun Undang-Undang Nomor 8 Tahun 1981 tentang Kitab Undang-Undang Hukum Acara Pidana (selanjutnya disebut KUHAP). Ketentuan mengenai pengaduan di dalam KUHP antara lain diatur pada Pasal

26 Putusan Mahkamah Agung Nomor 1600 K/Pid/ 2009, 2009.
$74^{27}$ dan pasal $75 .{ }^{28}$

Menurut hukum, apabila pengaduan dilakukan lebih dari enam bulan sejak orang yang berhak mengadu mengetahui adanya kejahatan (jika bertempat tinggal di Indonesia) atau lebih dari sembilan bulan (jika yang berhak mengadu bertempat tinggal di luar Indonesia), maka terhadap tindak pidana yang diadukan tersebut menjadi kadaluarsa karena telah melebihi jangka waktu yang dibatasi di dalam Pasal 74 KUHP.

Menurut yurisprudensi Mahkamah Agung Nomor 57/K/Kr/1968, Pasal 74 KUHP merupakan bagian dari pada Hukum Acara Pidana yang bersifat mengikat. Oleh karena itu, dalam delik aduan, jangka waktu yang dimaksud dalam Pasal 74 ayat (1) KUHP adalah dihitung sejak yang berhak mengadu mengetahui perbuatan yang dilakukan, bukan sejak diketahui perbuatan yang dilakukan benar atau tidak. ${ }^{29}$ Laporan dan pengaduan adalah terminologi hukum yang berbeda menurut KUHAP. ${ }^{30}$

27 Berdasarkan Pasal 74 KUHP, disebutkan bahwa: Pengaduan hanya boleh diajukan dalam waktu enam bulan sejak orang yang berhak mengadu mengetahui adanya kejahatan, jika bertempat tinggal di Indonesia, atau dalam waktu sembilan bulan jika bertempat tinggal di luar Indonesia. Jika yang terkena kejahatan berhak mengadu pada saat tenggang waktu tersebut belum habis, maka setelah saat itu, pengaduan masih boleh diajukan hanya selama sisa yang masih kurang pada tenggang waktu tersebut. Selengkapnya lihat: Undang-Undang Nomor 1 Tahun 1946 Tentang Peraturan Hukum Pidana (Republik Indonesia, 1946).

28 Berdasarkan Pasal 75 KUHP, disebutkan bahwa orang yang mengajukan pengaduan, berhak menarik kembali dalam waktu tiga bulan setelah pengaduan diajukan. Berdasarkan logika hukumnya maka apabila orang yang mengajukan pengaduan tidak menarik kembali pengaduan yang diajukannya dalam jangka waktu tiga bulan maka terhadap perkara yang diadukannya tersebut ditindaklanjuti sesuai ketentuan hukum acara yang berlaku. Selengkapnya lihat: Ibid.

29 Putusan Mahkamah Agung Nomor 57/K/Kr/ 1968, 1968.

30 Laporan menurut Pasal 1 angka 24 KUHAP adalah pemberitahuan yang disampaikan oleh seorang karena hak atau kewajiban berdasarkan undang-undang kepada pejabat yang berwenang 


\section{Batas Waktu Pencabutan Pengaduan}

Menurut Mahkamah Agung, walaupun pencabutan pengaduan telah melewati 3 bulan, yang menurut Pasal 75 KUHP telah lewat waktu, namun dengan pencabutan itu keseimbangan yang terganggu dengan adanya tindak pidana tersebut telah pulih. Pencabutan pengaduan merupakan tindakan untuk memaafkan (bisa dilakukan dengan didahului atau tanpa didahului perjanjian perdamaian, pen) yang dengan demikian pihak yang dirugikan merasa tidak perlu lagi perkara yang diadukannya untuk diteruskan. Oleh karena itu, meskipun delik aduan merupakan perkara pidana, namun perdamaian yang terjadi antara pelaku dan korban mengandung nilai yang tinggi yang harus diakui, karena bagaimanapun juga terdapat kemungkinanapabila perkara yang terkait dengan delik aduan dihentikan maka manfaatnya lebih besar dari pada bila dilanjutkan sesuai dengan ketentuan hukum acara yang berlaku (dimulai dari tindakan

tentang telah atau sedang atau diduga akan terjadinya peristiwa pidana. Sedangkan yang dimaksud dengan pengaduan menurut Pasal 1 angka 25 KUHAP adalah pemberitahuan disertai permintaan oleh pihak yang berkepentingan kepada pejabat yang berwenang untuk menindak menurut hukum seorang yang telah melakukan tindak pidana aduan yang merugikannya. Menurut Pasal 103 KUHAP, pada tahap penyelidikan, laporan atau pengaduan yang diajukan secara tertulis harus ditandatangani oleh pelapor atau pengadu sedangkan laporan atau pengaduan yang diajukan secara lisan harus dicatat oleh penyelidik dan ditandatangani oleh pelapor atau pengadu dan penyelidik. Dalam hal pelapor atau pengadu tidak dapat menulis, hal itu harus disebutkan sebagai catatan dalam laporan atau pengaduan tersebut. Sedangkan pada tahap penyidikan, menurut Pasal 108 ayat (4), Pasal 108 ayat (5), dan Pasal 108 ayat (5), KUHAP, laporan atau pengaduan yang diajukan secara tertulis harus ditandatangani oleh pelapor atau pengadu. Laporan atau pengaduan yang diajukan secara lisan harus dicatat oleh penyidik dan ditandatangani oleh pelapor atau pengadu dan penyidik. Selengkapnya lihat: UndangUndang Nomor 8 Tahun 1981 tentang Kitab Undang-Undang Hukum Acara Pidana (Republik Indonesia, 1981). penyelidikan sampai dengan pemasyarakatan apabila terhadap pelaku dinyatakan terbukti bersalah oleh pengadilan melakukan tindak pidana, pen). ${ }^{31}$

\section{Hukum Positif Indonesia menegaskan Tindak Pidana di Bidang Hak Cipta merupakan Delik Aduan}

Menurut ketentuan pidana pada Pasal 120 UUHC, yang dengan tegas menyebutkan bahwa tindak pidana sebagaimana dimaksud dalam undang-undang ini merupakan delik aduan, ${ }^{32}$ maka berdasarkan uraian sebelumnya mengenai KUHP, KUHAP, dan yurisprudensi, diketahui bahwa dasar pemeriksaan dari semua jenis tindak pidana di dalam UUHC adalah dalam bentuk adanya pengaduan, bukan dalam bentuk adanya laporan. Hal ini sangat penting untuk dipahami karena terdapat perbedaan apabila Hukum Pidana ditinjau secara luas (Hukum Pidana Materiil dan Hukum Pidana Formil).

Terhadap suatu tindak pidana aduan (klacht delict) maka pengaduan dari pihak yang berhak merupakan syarat sahnya penuntutan. Dalam penyusunan uraian dakwaannya pun juga terdapat perbedaan, artinya terhadap tindak pidana yang termasuk dalam tindak pidana aduan, haruslah diuraikan dengan jelas, lengkap dan cermat tentang pengaduan tersebut, yakni hal-hal yang terkait dengan:

31 Putusan Mahkamah Agung Nomor 1600 K/Pid/ 2009.

32 Delik aduan memiliki kekhususan, yaitu penuntutan terhadap seorang pelaku tindak pidana sangat bergantung dari ada tidaknya pengaduan dari orang yang menjadi korban atau pihak yang dirugikan. Oleh karena itu, sangat tepat suatu adagium yang menyebutkan bahwa Wo Kein Klager Ist, Ist Kein Richter (Kalau tidak ada tuntutan hak, maka tidak ada peradilan). Selengkapnya lihat: Duwi Handoko, Asasasas Hukum Pidana dan Hukum Penitensier di Indonesia (Dilengkapi dengan Evaluasi Pembelajaran dalam Bentuk Teka-Teki Silang Hukum dan Disertai dengan Humor dalam Lingkup IImu dan Pengetahuan tentang Hukum) (Pekanbaru: Hawa dan AHWA, 2017). 
a. Siapa yang berhak mengajukan pengaduan?

b. Kapan harus dilakukan pengaduan?

c. Apakah pengaduan bisa dicabut atau tidak bisa dicabut?

d. Apakah ada tentang daluarsa pengaduan?

e. Apakah ada tentang daluarsa pencabutan pengaduan? ${ }^{33}$

Terkait dengan klasifikasi tindak pidana di dalam UUHC yang dikategorikan sebagai delik aduan, maka menurut penulis pembentuk undang-undang tersebut mengulangi kembali klasifikasi delik aduan tersebut sesuai dengan pemikiran penguasa negara (pembentuk undang-undang) hak cipta pada tahun 1982 yang kemudian diklasifikasikan menjadi delik biasa menurut undang-undang hak cipta pada tahun 1987, pada tahun 1997, dan pada tahun 2002. Untuk lebih jelasnya, di bawah ini diuraikan tentang klasifikasi delik menurut undang-undang hak cipta, ${ }^{34}$ yang pernah berlaku di Indonesia sampai dengan yang berlaku saat ini.

\section{a. Klasifikasi Delik Hak Cipta menurut Undang-Undang Hak Cipta Tahun 1982}

Menurut undang-undang ini, tindak pidana di bidang hak cipta merupakan delik aduan. Hal ini sesuai ketentuan Pasal 45 dari undang-undang tersebut, yaitu tindak pidana sebagaimana dimaksud dalam Pasal 44 tidak dapat dituntut kecuali atas pengaduan dari pemegang hak cipta. Pembentuk undang-undang ini tidak memberikan dasar pemikiran mengapa delik di bidang hak cipta dikategorikan sebagai delik aduan.

33 Putusan Mahkamah Agung Nomor $2158 \mathrm{~K} /$ Pid/2007, 2007.

34 Duwi Handoko, Hukum Positif mengenai Hak Kekayaan Intelektual di Indonesia (Jilid II) (Pekanbaru: Hawa dan AHWA, 2015).

\section{b. Klasifikasi Delik Hak Cipta menurut Undang-Undang Hak Cipta Tahun 1987}

Menurut undang-undang ini, tindak pidana di bidang hak cipta merupakan delik biasa. Hal ini karena ketentuan Pasal 45 dihapus dan diganti dengan ketentuan Pasal 45 baru yang berbunyi sebagai berikut: "Ciptaan atau barang yang merupakan hasil pelanggaran Hak Cipta dirampas untuk Negara guna dimusnahkan". Selanjutnya, ketentuan Pasal 46 dihapus dan diganti dengan ketentuan Pasal 46 baru yang berbunyi sebagai berikut: "Tindak pidana sebagaimana dimaksud dalam Pasal 44 adalah kejahatan". Alasan pembentuk undang-undang mengubah kategori delik di bidang hak cipta, yaitu dari klasifikasi delik aduan menjadi delik biasa dapat diketahui dari penjelasan umum undang-undang tersebut, yaitu: Dalam upaya untuk meningkatkan efektivitas penindakan, ketentuan bahwa pelanggaran terhadap Hak Cipta merupakan tindak pidana aduan, dinilai tidak sesuai dengan kebutuhan. Pelanggaran tersebut seharusnya memang diperlakukan sebagai tindak pidana biasa. Penindakannya, dengan begitu tidak lagi semata-mata didasarkan pada adanya pengaduan. Dihapuskannya ketentuan Pasal 45 Undang-Undang Nomor 6 Tahun 1982, mengakibatkan pelanggaran terhadap hak cipta tidak lagi merupakan tindak pidana aduan, melainkan tindak pidana biasa. Dengan demikian penindakan dapat segera dilakukan tanpa perlu menunggu adanya pengaduan dari pemegang hak cipta yang haknya dilanggar.

\section{c. Klasifikasi Delik Hak Cipta menurut Undang-Undang Hak Cipta Tahun 1997}

Menurut undang-undang ini, pelanggaran terhadap hak cipta tetap dipertahankan sebagai tindak pidana biasa. 


\section{d. Klasifikasi Delik Hak Cipta menurut Undang-Undang Hak Cipta Tahun 2002}

Tidak ada satu pasal pun yang menegaskan bahwa tindak pidana di bidang hak cipta dalam undang-undang ini merupakan delik aduan atau delik biasa.

\section{e. Klasifikasi Delik Hak Cipta menurut Undang-Undang Hak Cipta Tahun 2014}

Undang-undang ini menegaskan bahwa tindak pidana di bidang hak cipta dalam undang-undang tersebut merupakan delik aduan. Hal ini ditegaskan pada Pasal 120 UUHC.

Berdasarkan Risalah Resmi Rapat Paripurna DPR RI, penerapan delik aduan untuk tuntutan pidana di bidang hak cipta sebagaimana diatur di dalam Pasal 120 UUHC tersebut menurut pemerintah sebagai salah satu pihak yang membentuknya merupakan hal yang penting. ${ }^{35}$

Menurut Priyo Budi Santoso selaku Ketua Rapat Paripurna DPR RI tersebut di atas, terkait dengan persetujuan atas disahkannya RUU tentang Hak Cipta, maka Undang-Undang tentang Hak Cipta yang baru tersebut adalah salah satu mahakarya atau karya besar DPR periode 2009-2014. Hal tersebut karena para musisi, pencipta lagu, seniman besar, budayawan, ekonomi kreatif, designer-designer dan seterusnya sangat berharap dan menunggu cukup lama terhadap kelahiran rancangan undang-undang ini dalam hal memberikan perlindungan hukum terhadap hak karya ciptanya. ${ }^{36}$

Berdasarkan uraian di atas, menurut penulis, masih terdapat kelemahan substansi dari Pasal 120 UUHC. Kelemahan tersebut berdasarkan hasil penelitian ini, dapat ditinjau dari beberapa aspek, diantaranya adalah:

\footnotetext{
35 Risalah Resmi Rapat Paripurna DPR RI pada Hari Selasa, Tanggal 16 September 2014, 2014.

1. Pasal 120 UUHC yang berlaku saat ini, tidak menyebutkan dengan tegas dan jelas siapakah pihak yang berhak melakukan pengaduan (apakah cukup hanya pencipta dan/atau semua pencipta (apabila lebih dari satu orang pencipta) dan/atau pemegang hak cipta). Hal ini tentunya berbeda apabila dibandingkan dengan ketentuan Pasal 45 UUHC yang pernah berlaku berdasarkan UndangUndang Nomor 6 Tahun 1982 tentang Hak Cipta yang secara tegas dan jelas mengatur ketentuan sebagai berikut: "Tindak pidana sebagaimana dimaksud dalam Pasal 44 tidak dapat dituntut kecuali atas pengaduan dari pemegang hak cipta".

2. Pasal 120 UUHC yang berlaku saat ini, tidak menyebutkan dengan tegas dan jelas mengenai apakah pengaduan masih tetap diproses apabila terhadap para pihak (dalam keadaan tertentu terdapat lebih dari satu orang karena lebih dari satu orang pencipta) yang berhak melakukan pengaduan, hanya diadukan oleh satu orang saja atau pengaduan tidak dilakukan oleh seluruh pihak yang berhak mengadukan.

Selanjutnya, terkait dengan bagaimana sikap yang seharusnya dari pencipta atau pemegang hak cipta dalam menyikapi delik aduan dibidang hak cipta, penulis memberikan rekomendasi yang sebaiknya dilakukan sebelum pihak yang berhak melakukan pengaduan. Rekomendasi ini pada pokoknya mengharapkan pihak yang berhak melakukan pengaduan mempertimbangkan dua hal, yaitu:

1. Lakukan kalkulasi atau perhitungan apabila ingin melakukan pengaduan, yaitu apa saja keuntungan dan/atau kerugian dalam hal menuntut pelaku secara Hukum Pidana. Perhitungan tersebut tentunya tidak terbatas hanya kepada perhitungan secara ekonomis.

2. Kalkulasi lainnya adalah terkait dengan ketentuan hukum yang diatur di dalam 
Pasal 75 KUHP, yaitu adanya batas waktu (dalam waktu tiga bulan) untuk menarik kembali pengaduan yang diajukan. Hal ini erat kaitannya dengan adanya upaya penyelesaian perkara pidana secara non litigasi sebagai pola penerapan prinsip ultimum remedium.

\section{Dasar Pemikiran Proses Dekriminalisasi Ditinjau dari Pembentukan UUHC}

Menurut Konstitusi, Negara Indonesia adalah negara hukum (Pasal 1 Ayat (3)). Masih menurut konstitusi, segala warga negara bersamaan kedudukannya di dalam hukum dan pemerintahan dan wajib menjunjung hukum dan pemerintahan itu dengan tidak ada kecualinya (Pasal 27 Ayat (1)). Kewajiban segala warga negara untuk menjunjung hukum salah satunya menurut penulis dapat dimaknai keharusan setiap warga negara untuk melakukan misi mulia, yaitu menghormati hukum dan dengan sekuat tenaga tidak melakukan sesuatu pelanggaran hukum. Hal ini karena pelanggaran hukum dapat dilakukan oleh siapa saja, di mana saja, dan kapan saja, tidak terkecuali pelanggaran Hukum Pidana di bidang Hak Cipta karena adanya proses kriminalisasi oleh organ-organ negara.

Menurut Nella Sumika Putri, Indonesia adalah negara yang dapat digolongkan sebagai penganut tradisi Civil Law dimana sumber hukum utamanya adalah undangundang dan kodifikasi. Apabila dihubungkan dengan hukum pidana, setiap perbuatan dapat dikategorikan sebagai kejahatan jika perbuatan tersebut telah dikriminalisasi oleh undang-undang atau kodifikasi. Prinsip ini dikenal dengan istilah asas legalitas yang menimbulkan suatu konsekuensi, yaitu suatu perbuatan yang dapat dipidana harus didasarkan pada undang-undang, tidak dapat diterapkannya asas retroaktif, lex stricta, dan tidak memperkenankan penafsiran secara analogi. ${ }^{37}$

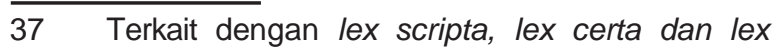

Kembali pada persoalan kriminalisasi dan dekriminalisasi, ditinjau dari pengertiannya, kriminalisasi menurut J.E. Sahetapy, adalah proses mengangkat perbuatan yang semula bukan perbuatan pidana menjadi perbuatan yang dapat dipidana. Proses kriminalisasi ini terdapat didalam tahap formulasi dari pembaharuan hukum pidana. Sedangkan dekriminalisasi dapat diartikan sebagai proses menghilangkan sifat dapat dipidananya perbuatan menjadi tidak dapat dipidana. Selain itu masih ada istilah depenalisasi. Penghilangan sifat dapat dipidana ini tidak mudah, karena harus mempertimbangkan berbagai aspek yang berhubungan dengan jenis perbuatan yang dilakukan oleh pelaku tindak pidana, di samping aspek keadilan. Masalah kriminalisasi ini erat kaitannya dengan criminal policy. ${ }^{38}$

stricta, Jan Remmelink, berpendapat:

a. Lex Scripta. Dalam tradisi civil law, aspek pertama adalah penghukuman harus didasarkan pada undang-undang, dengan kata lain berdasarkan hukum yang tertulis. Undang-undang (statutory, law) harus mengatur mengenai tingkah laku (perbuatan) yang dianggap sebagai tindak pidana. Tanpa undang-undang yang mengatur mengenai perbuatan yang dilarang, maka perbuatan tersebut tidak bisa dikatakan sebagai tindak pidana. Hal ini berimplikasi bahwa kebiasaan tidak bisa dijadikan dasar menghukum seseorang.

b. Lex Certa dan Lex Stricta. Dalam kaitannya dengan hukum yang tertulis, pembuat undangundang (legislatif) harus merumuskan secara jelas dan rinci mengenai perbuatan yang disebut dengan tindak pidana (kejahatan, crimes). Hal inilah yang disebut dengan asas lex certa atau bestimmtheitsgebot. Pembuat undang-undang harus mendefinisikan dengan jelas tanpa samarsamar (nullum crimen sine lege stricta), sehingga tidak ada perumusan yang ambigu mengenai perbuatan yang dilarang dan diberikan sanksi. Perumusan yang tidak jelas atau terlalu rumit hanya akan memunculkan ketidakpastian hukum. Selengkapnya lihat: Agustinus Pohan, Topo Santoso, dan Martin Moerings, eds., Hukum Pidana dalam Perspektif (Bali: Pustaka Larasan, 2012).

38 Criminal policy adalah usaha yang rasional baik dari masyarakat/pemerintah untuk menanggulangi tindak pidana baik menggunakan sarana penal maupun non-penal. Menurut Soedarto, ada 4 (empat) syarat yang harus diperhatikan di dalam melakukan kriminalisasi, yaitu: 
Berdasarkan laporan Simposium Hukum Pidana Nasional tahun 1980 yang diadakan di Semarang, disebutkan bahwa masalah kriminalisasi dan dekriminalisasi atas suatu perbuatan haruslah sesuai dengan politik kriminal yang dianut oleh bangsa Indonesia, yaitu sejauh mana perbuatan tersebut bertentangan dengan nilai-nilai fundamental yang berlaku dalam masyarakat dan oleh masyarakat dianggap patut atau tidak patut dihukum dalam rangka menyelenggarakan kesejahteraan masyarakat. ${ }^{39}$ Termasuk dalam pengertian kriminalisasi adalah sebagaimana yang dinyatakan oleh Paul Cornil, yaitu peningkatan jumlah ancaman pidana untuk suatu perbuatan tertentu. ${ }^{40}$

Menurut Mardjono Reksodiputro, terdapat dua bentuk kriminalisasi, yaitu kriminalisasi primair (kriminalisasi oleh pembuat undang-undang) dan yang kriminalisasi secundaire (kriminalisasi oleh penegak hukum dalam Sistem Peradilan Pidana). Perlu juga dipahami pengertian dekriminalisasi (ada yang melalui perbuatan pembuat undang-undang dan ada pula oleh penegak hukum dalam Sistem Peradilan Pidana). Kriminalisasi primer adalah kriminalisasi dalam bentuk abstrak (in abstracto) sedangkan pasangannya yang

a. Tujuan: Tujuan kriminalisasi adalah menciptakan ketertiban masyarakat di dalam rangka menciptakan negara kesejahteraan (welfare state).

b. Perbuatan: Perbuatan yang dikriminalisasi harus perbuatan yang menimbulkan kerusakan meluas dan menimbulkan korban.

c. Biaya dan Hasil: Harus dipertimbangkan faktor biaya dan hasil dalam arti biaya yang dikeluarkan dan hasil yang diperoleh harus seimbang.

d. Kemampuan Aparat Penegak Hukum: Jangan sampai aparat penegak hukum melampaui bebannya atau melampaui batas. Tujuan kriminalisasi ini berstandarkan pada keseimbangan antara beban aparat dengan beban masyarakat.

Selengkapnya lihat: Sahetapy, Problematika Pembaruan Hukum Pidana Nasional.

39 Fajrimei A. Gofar, Asas Legalitas Dalam Rancangan KUHP (Jakarta: ELSAM-Lembaga studi dan Advokasi Masyarakat, 2005).

40 Arief, Kebijakan Legislatif dalam Penanggulangan Kejahatan dengan Pidana Penjara. sekunder adalah dalam bentuk konkrit (in concreto). ${ }^{41}$

Beberapa prinsip Hak Asasi Manusia dalam kriminalisasi tersebut di atas adalah sebagai berikut:

1. Hukum Pidana memang dapat digunakan untuk menegaskan (atau menegaskan kembali) sejumlah nilai sosial yang mendasar (basic social values) bagi pembentukan perilaku hidup bermasyarakat.

2. Hukum Pidana sedapat mungkin hanya digunakan dalam keadaan di mana cara lain melakukan pengendalian sosial tidak dapat efektif (asas ultimum remedium dan asas subsidiaritas).

3. Dalam menggunakan Hukum Pidana sesuai kedua prinsip di atas, maka harus diusahakan agar caranya seminimal mungkin mengganggu hak dan kebebasan individu, tanpa mengurangi perlindungan terhadap kepentingan kolektivitas dalam masyarakat demokratis dan modern. ${ }^{42}$

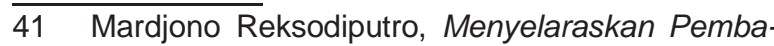
ruan Hukum (Jakarta: Komisi Hukum Nasional RI, 2009).

42 Menurut ilmu Hukum Pidana "kriminalisasi" (primair: menyatakan sebagai tindak pidana perbuatan dalam abstracto, sedangkan secundaire: memberi label pelanggar hukum pidana pada orang dalam concreto), selalu berkaitan dengan kerugian pada pihak lain (dalam hal "crime without victims" tetap dianggap ada kerugian pada masyarakat). Tetapi untuk menguji suatu kriminalisasi primair tidaklah cukup hanya diuji pada satu asas itu (adanya kerugian), tetapi ada pula sejumlah asas yang patut diperhatikan. Sejumlah asas tersebut adalah sebagai berikut:

a. Asas bahwa kerugian yang digambarkan oleh perbuatan tersebut harus masuk akal, adapun kerugian ini dapat mempunyai aspek moral (moralitas individu-kelompok-kolektivitas), tetapi selalu harus merupakan "public issue";

b. Asas adanya toleransi (tenggang rasa) terhadap perbuatan tersebut (penilaian atas terjadinya kerugian, berkaitan erat dengan ada atau tidak adanya toleransi; toleransi didasarkan pada penghormatan atas kebebasan dan tanggung jawab individu);

c. Asas subsidiaritas (sebelum perbuatan dinyatakan sebagai tindak pidana, perlu diperhatikan apakah kepentingan hukum yang terlanggar oleh perbuatan tersebut masih dapat dilindungi 
Beralih pada pembahasan mengenai dekriminalisasi, menurut Alfitra, dekriminalisasi adalah suatu proses di mana dihilangkan sama sekali sifat dapat dipidananya suatu perbuatan. ${ }^{43}$ Oleh karena itu, penulis berpendapat apabila terjadi dekriminalisasi, maka penuntutan terhadap perbuatan yang sudah dihilangkan sama sekali sifat dapat dipidananya perbuatan itu, harus dihentikan.

Berdasarkan hal tersebut di atas, maka dalam merencanakan kriminalisasi suatu perbuatan, perlu disepakati dahulu tentang terhadap ancaman "apa saja" (what kind of threat) dan "oleh siapa" (who is a potential offender). Tahap berikutnya adalah menyesuaikan dengan politik kriminal pemerintah/negara (strategi penanggulangan perbuatan tercela tersebut). Perlu diperhatikan di sini keterbatasan suatu sanksi pidana, maupun kemungkinan cacatcacatnya (intervensi dan pelanggaran asas kebebasan dalam negara demokrasi). Kalau sudah yakin bahwa perbuatan tertentu perlu dikriminalisasi karena potensial menimbulkan kerugian pada pihak lain, maka masih harus diperhatikan asas toleransi (masyarakat dan negara). Mungkin diperlukan suatu skema sederhana untuk menentukan (a) padanan antara pidana penjara (dan mati?) dengan

dengan cara lain; hukum pidana hanyalah ultimum remedium);

d. Asas proporsionalitas (harus ada keseimbangan antara kerugian yang digambarkan dengan batasbatas yang diberikan oleh asas toleransi, dan dengan reaksi atau pidana yang diberikan);

e. Asas legalitas, apabila poin 1 sampai dengan 4 telah dipertimbangkan, masih perlu dilihat apakah perbuatan tersebut dapat dirumuskan dengan baik hingga kepentingan hukum yang akan dilindungi, tercakup dan pula jelas hubungannya dengan asas kesalahan, yang merupakan sendi utama hukum pidana;

f. Asas penggunaannya secara praktis, dan efektivitasnya berkaitan dengan kemungkinan penegakkannya serta dampaknya pada prevensi umum (practical use and effectivity).

Selengkapnya lihat: Ibid.

43 Alfitra, Hapusnya Hak Menuntut dan Menjalankan Pidana (Bogor: Raih Asa Sukses, 2012). denda; (b) penggunaan pidana minimal khusus; dan (c) penggunaan ancaman pidana: alternatif atau kumulatif (kumulatifalternatif apakah perlu?). ${ }^{44}$

Definisi dekriminalisasi berdasarkan salah satu putusan Mahkamah Konstitusi adalah suatu proses menghilangkan sifat dilarang dan diancam pidana dari suatu tindakan pidana yang semula merupakan tindak pidana menjadi tindakan yang tidak dilarang dan tidak diancam pidana. ${ }^{45}$ Oleh karena itu, menurut Duwi Handoko, dekriminalisasi hanya menjadi kewenangan atau kekuasaan dari lembaga pembentuk undang-undang dan lembaga pembentuk peraturan daerah provinsi/ kabupaten/ kota. Lembaga-lembaga negara tersebut (dalam cabang kekuasaan legislatif dan cabang kekuasaan eksekutif), tentunya juga diberikan kewenangan untuk melakukan dekriminalisasi. ${ }^{46}$

Menurut hukum positif di Indonesia, kriminalisasi merupakan kewenangan mutlak dari para pembentuknya (cabang kekuasaan legislatif dan kekuasaan eksekutif), baik dalam bentuk undang-undang maupun peraturan daerah provinsi/kabupaten/kota. Sedangkan kewenangan melakukan dekriminalisasi tidak menjadi kewenangan mutlak cabang kekuasaan legislatif dan eksekutif tersebut. Hal ini karena dekriminalisasi juga menjadi kewenangan cabang kekuasaan yudikatif seperti yang telah dipraktikkan oleh Mahkamah Konsitusi pada saat ini. ${ }^{47}$

44 Reksodiputro, Menyelaraskan Pembaruan Hukum.

45 Putusan Mahkamah Konstitusi Nomor 21/PUUVIII/2010, 2010.

46 Handoko, Kriminalisasi dan Dekriminalisasi di Bidang Hak Cipta.

47 Secara umum, putusan MK bersifat pertama dan terakhir serta bersifat final dan mengikat. Sedangkan putusan MA secara umum, tidak bersifat pertama dan terakhir karena terdapat putusan pengadilan yang bersifat final dan mengikat dan ada pula putusan yang bersifat belum final akan tetapi sudah mengikat. Selengkapnya lihat: Duwi Handoko, Kekuasaan 
Berdasarkan uraian di atas, secara umum (kecuali ketentuan pidana pada Pasal 114, Pasal 119 dan Pasal 120), setiap tindak pidana sebagaimana diatur di dalam UUHC memuat salah satu unsur tindak pidana yang menurut penulis merupakan salah satu unsur pokok, yaitu berupa "secara komersial". Oleh karena itu, salah satu proses dekriminalisasi dibidang hak cipta secara ekstrim menurut penulis adalah warga negara oleh pembentuk UUHC (lembaga legislatif dan lembaga eksekutif) "dibolehkan" untuk melanggar hak cipta yang dihasilkan oleh pencipta dengan batasan, yaitu pelanggaran yang dilakukan tersebut tidak memasuki ranah atau lingkup untuk digunakan secara komersial.

Sebelum UUHC diberlakukan, khususnya pada saat Undang-Undang Nomor 19 Tahun 2002 tentang Hak Cipta masih berlaku, hanya terdapat 1 (satu) ketentuan pidana yang mengatur tentang penggunaan secara komersial. Hal ini berarti menurut pembentuk Undang-Undang Nomor 19 Tahun 2002 tentang Hak Cipta, apabila terjadi pelanggaran hak cipta meskipun pelanggaran tersebut bukan bertujuan untuk kepentingan komersial, penegak hukum dapat melakukan tindakan. Hal ini berbeda dengan pemikiran pembentuk UUHC, yaitu penegak hukum baru dapat melakukan tindakan apabila pelanggaran hak cipta tersebut sudah memenuhi unsur dilakukan untuk kepentingan komersial.

Pembentuk UUHC tidak mengatur ketentuan pidana terhadap subjek hukum yang melakukan pengumuman ciptaan yang bertentangan dengan kebijaksanaan pemerintah di bidang agama, pertahanan dan keamanan negara, kesusilaan, serta ketertiban umum. Sedangkan di dalam Undang-Undang Nomor 19 Tahun 2002 tentang Hak Cipta, hal tersebut diatur pada Pasal 72 Ayat (4).

Kehakiman di Indonesia (Pekanbaru: Hawa dan AHWA, 2015).
Pembentuk UUHC, juga tidak mengatur ketentuan pidana terhadap subjek hukum yang dengan sengaja melanggar peraturan perizinan ciptaan-ciptaan yang menggunakan sarana produksi berteknologi tinggi, khususnya di bidang cakram optik (optical disc) dan tidak memenuhi semua dan persyaratan produksi yang ditetapkan oleh instansi yang berwenang. Sedangkan di dalam Undang-Undang Nomor 19 Tahun 2002 tentang Hak Cipta, hal tersebut diatur pada Pasal 72 Ayat (9).

Dari hal tersebut di atas, maka terdapat dekriminalisasi oleh pembentuk UUHC. Dekriminalisasi tersebut adalah sebagai berikut:

1. Pidana tidak dijatuhkan atas perbuatan pelanggaran hak cipta yang tidak memiliki kepentingan secara komersial.

2. Pidana tidak dijatuhkan atas perbuatan berupa melakukan pengumuman ciptaan yang bertentangan dengan kebijaksanaan pemerintah di bidang agama, pertahanan dan keamanan negara, kesusilaan, serta ketertiban umum.

3. Pidana tidak dijatuhkan atas perbuatan berupa melanggar peraturan perizinan ciptaan-ciptaan yang menggunakan sarana produksi berteknologi tinggi, khususnya di bidang cakram optik (optical disc) dan tidak memenuhi semua dan persyaratan produksi yang ditetapkan oleh instansi yang berwenang.

\section{PENUTUP}

\section{Kesimpulan}

Dasar pemikiran proses kriminalisasi ditinjau dari pembentukan UUHC dapat ditinjau dari dua aspek, yaitu kriminalisasi murni dan bukan kriminalisasi murni. Kriminalisasi murni oleh pembentuk UUHC adalah sebagaimana diatur di dalam Pasal 114, Pasal 115, dan Pasal 119 UUHC. Sedangkan "pasangannya", yaitu bukan 
kriminalisasi murni adalah sebagaimana diatur di dalam Pasal 112, Pasal 113, Pasal 116, Pasal 117, Pasal 118, dan Pasal 120 UUHC. Dasar pemikiran terhadap kriminalisasi murni oleh pembentuk UUHC adalah: 1) Pengelola tempat perdagangan harus bertanggung jawab atas tempat penjualan dan/atau pelanggaran hak cipta dan/atau hak terkait di pusat tempat perbelanjaan yang dikelolanya;

2) Subjek hukum harus bertanggung jawab dalam hal pemuatan potret pada iklan, banner, billboard, kalender, dan pamflet yang digunakan secara komersial tanpa persetujuan dari orang yang dipotret atau ahli warisnya; dan 3) Setiap lembaga manajemen kolektif harus bertanggung jawab atas tindakan yang dilakukannya, yaitu berupa tanpa izin operasional dari menteri dalam hal melakukan kegiatan penarikan royalti.

Dasar pemikiran proses dekriminalisasi ditinjau dari pembentukan UUHC adalah: 1) Pidana tidak dijatuhkan atas perbuatan pelanggaran hak cipta yang tidak memiliki kepentingan secara komersial; 2) Pidana tidak dijatuhkan atas perbuatan berupa melakukan pengumuman ciptaan yang bertentangan dengan kebijaksanaan pemerintah di bidang agama, pertahanan dan keamanan negara, kesusilaan, serta ketertiban umum; dan 3) Pidana tidak dijatuhkan atas perbuatan berupa melanggar peraturan perizinan ciptaan-ciptaan yang menggunakan sarana produksi berteknologi tinggi, khususnya di bidang cakram optik (optical disc) dan tidak memenuhi semua dan persyaratan produksi yang ditetapkan oleh instansi yang berwenang.

\section{Saran}

Berdasarkan kesimpulan tersebut di atas, direkomendasikan beberapa hal seperti yang disebutkan di bawah ini:

1. Meminta kepada pemerintah untuk secara terus menerus memberikan edukasi kepada masyarakat mengenai hak cipta, khususnya terkait dengan bagaimana sikap yang seharusnya dari pencipta atau pemegang hak cipta dalam menyikapi delik aduan di bidang hak cipta. Dalam hal ini, penulis memberikan dua rekomendasi yang sebaiknya dilakukan sebelum pihak yang berhak melakukan pengaduan, yaitu: a) Lakukan kalkulasi atau perhitungan apabila ingin melakukan pengaduan, yaitu apa saja keuntungan dan/atau kerugian dalam hal menuntut pelaku secara Hukum Pidana. Perhitungan tersebut tentunya tidak terbatas hanya kepada perhitungan secara ekonomis; dan b) Kalkulasi lainnya terkait dengan ketentuan hukum yang diatur di dalam Pasal 75 KUHP, yaitu adanya batas waktu (dalam waktu tiga bulan) untuk menarik kembali pengaduan yang diajukan. Hal ini erat kaitannya dengan adanya upaya penyelesaian perkara pidana secara non litigasi sebagai pola penerapan prinsip ultimum remedium.

2. Meminta kepada pencipta untuk terus berkarya dan memahami tidak semua perbuatan di bidang hak cipta yang memenuhi unsur-unsur pidana dapat dinyatakan sebagai kejahatan dan terhadap pelakunya disebut penjahat. Hal itu karena terdapat legalisasi terhadap pelanggaran di bidang hak cipta itu sendiri. Kajian secara komprehensif tentang hal tersebut tentunya merupakan kajian politik hukum kontemporer berbasis pada man madelaw yang menarik.

\section{UCAPAN TERIMA KASIH}

Penulisan ini didukung oleh Sekolah Tinggi Ilmu Hukum Persada Bunda serta Penerbit Hawa dan AHWA. 


\section{DAFTAR PUSTAKA}

Alfitra. Hapusnya Hak Menuntut Dan Menjalankan Pidana. Bogor: Raih Asa Sukses, 2012.

Arief, Barda Nawawi. Bunga RampaiKebijakan Hukum Pidana: (Perkembangan Penyusunan Konsep KUHP Baru). Jakarta: Kencana, 2011.

_-_. Kapita Selekta Hukum Pidana. Bandung: Citra Aditya Bakti, 2003.

$\begin{array}{llr}\text { - Kebijakan } & \text { Legislatif } & \text { Dalam } \\ \text { Penanggulangan } & \text { Kejahatan } & \text { Dengan } \\ \text { Pidana Penjara. } & \text { Yogyakarta: Genta } \\ \text { Publishing, 2010. } & & \end{array}$

Effendi, Erdianto. Hukum Pidana Indonesia - Suatu Pengantar. Bandung: Refika Aditama, 2011.

Gofar, Fajrimei A. Asas Legalitas Dalam Rancangan KUHP. Jakarta: ELSAMLembaga studidanAdvokasi Masyarakat, 2005.

Handoko, Duwi. Asas-Asas Hukum Pidana Dan Hukum Penitensier Di Indonesia (Dilengkapi Dengan Evaluasi Pembelajaran Dalam Bentuk TekaTeki Silang Hukum Dan Disertai Dengan Humor Dalam Lingkup IImu Dan Pengetahuan Tentang Hukum). Pekanbaru: Hawa dan AHWA, 2017.

—. Dekriminalisasi Terhadap Delik-Delik Dalam KUHP. Pekanbaru: Hawa dan AHWA, 2016.

- Hukum Positif Mengenai Hak Kekayaan Intelektual Di Indonesia (Jilid II). Pekanbaru: Hawa dan AHWA, 2015. . Kekuasaan Kehakiman Di Indonesia. Pekanbaru: Hawa dan AHWA, 2015.

. Kriminalisasi Dan Dekriminalisasi Di Bidang Hak Cipta. Pekanbaru: Hawa dan AHWA, 2015.

_. "Pemidanaan Terhadap Kejahatan Tanpa Korban Berdasarkan Putusan Kasasi Tahun 2007-2012 (Analisis Yuridis Terhadap Tindak Pidana Perjudian)." Universitas Islam Riau, 2013.
Jimly Asshiddiqie. Konstitusi Dan Konstitusionalisme Indonesia. Jakarta: Konstitusi Press, 2005.

Kansil, C.S.T., and Christine S.T. Kansil. Latihan Ujian: Pengantar Hukum Indonesia. Jakarta: Sinar Grafika, 2007.

MD, Moh. Mahfud. Membangun Politik Hukum Menegakkan Konstitusi. Jakarta: Rajawali Pers, 2011.

__ Politik Hukum Di Indonesia. Jakarta: Rajawali Pers, 2010.

Nugroho, Trisapto Wahyudi Agung. "Analisis E-Government Terhadap Pelayanan Publik Di Kementerian Hukum Dan HAM (Analysis of E-Government to Public Services in the Ministry of Law and Human Rights)." JIKH 10, no. 3 (2016): 279-296.

Pohan, Agustinus, Topo Santoso, and Martin Moerings, eds. Hukum Pidana Dalam Perspektif. Bali: Pustaka Larasan, 2012.

Purba, Hasim. Pengantar Ilmu Hukum Indonesia. Medan: Fakultas Hukum Universitas Sumatera Utara, 2007.

Reksodiputro, Mardjono. Menyelaraskan Pembaruan Hukum. Jakarta: Komisi Hukum Nasional RI, 2009.

Sahetapy, J.E. Problematika Pembaruan Hukum Pidana Nasional. Jakarta: Komisi Hukum Nasional RI, 2013.

Simatupang, Taufik H. "Sistem Hukum Perlindungan Kekayaan Intelektual Dalam Rangka Meningkatkan Kesejahteraan Masyarakat (Law System of Intellectual Property Protection in Order to Improve People Prosperity)." Jurnal Penelitian Hukum DE JURE 17, no. 2 (2017): 195-208.

Soekanto, Soerjono, and Sri Mamudji. Penelitian Hukum Normatif. Jakarta: RajaGrafindo Persada, 2007.

Syahputra, Fernandes Edy, L. Erwina Silaban, and Mahmud Mulyadi. "Kebijakan Hukum Pidana Terhadap Pengaturan Tindak Pidana Narkotika Di Indonesia." Jurnal Mahupiki (2012). 
Syaukani, Imam, and A. Ahsin Thohari. DasarDasar Politik Hukum. Jakarta: Rajawali Pers, 2010.

Tarigan, Irwan Jasa. Narkotika Dan Penanggulangannya. Yogyakarta: Deepublish, 2017.

Wibowo, Ari. "Justifikasi Hukum Pidana Terhadap Kebijakan Kriminalisasi Pelanggaran Hak Cipta, Serta Perumusan Kualifikasi Yuridis Dan Jenis Deliknya." Jurnal Hukum Ius Quia lustum 22, no. 1 (2015): 54-75.

Putusan Mahkamah Agung Nomor $1600 \mathrm{~K} /$ Pid/2009, 2009.

Putusan Mahkamah Agung Nomor $2158 \mathrm{~K} /$ Pid/2007, 2007.

Putusan Mahkamah Agung Nomor 57/K/ Kr/1968, 1968.

Putusan Mahkamah Konstitusi Nomor 21/ PUU-VIII/2010, 2010.

Risalah Resmi Rapat Paripurna DPR RI Pada Hari Selasa, Tanggal 16 September 2014, 2014.

Undang-Undang Nomor 1 Tahun 1946 Tentang Peraturan Hukum Pidana. Republik Indonesia, 1946.

Undang-Undang Nomor 12 Tahun 2011 Tentang Pembentukan Peraturan Perundang-Undangan. Republik Indonesia, 2011.

Undang-Undang Nomor 8 Tahun 1981 Tentang Kitab Undang-Undang Hukum Acara Pidana. Republik Indonesia, 1981. 
